\title{
Enterprise Risk Management and Firm Performance: A Financial Sector Analysis of Pakistan
}

\author{
Dr. Muhammad Jawad ${ }^{a^{*}}$, Dr. Munazza Naz ${ }^{\mathrm{b}}$, Mr. Nauman Waheed

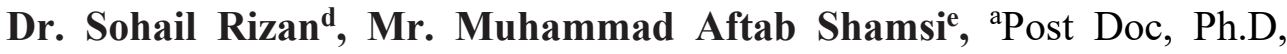 \\ Department of Commerce, Fatima Jinnah Women University, Pakistan. \\ *Corresponding Author, 'bost Doc, Ph.D, Department of Mathematics, \\ Fatima Jinnah Women University, Pakistan. ${ }^{\mathbf{c}, \mathbf{d}}$ Department of Commerce, \\ Fatima Jinnah Women University, Pakistan. 'University Institute of \\ Management Sciences, PMAS-Arid Agriculture University, Rawalpindi, \\ Pakistan. Email: $\quad a^{*}$ muhammad jawad85@yahoo.com, \\ bmunazzanaz@fjwu.edu.pk,_ cnauman_acc@yahoo.co.uk, \\ dsohaildotrizwan@gmail.com, ${ }^{\mathrm{e}}$ chaftabshamsi@gmail.com
}

Enterprise faces many kinds of risks and therefore the attention differs across institutions and organizations. Risk as an event that will influence the performance of a corporation as well as environmental risks, moral problems and social problems. Furthermore, risk or uncertainty as a broad and well-organized structure for managing different kinds of risks like credit, operational, marketplace, operative, economical or capital risks and risk transmission to maximize organization worth. The research analysis the different performance indicator of firm, enterprise risk management and their effect on firm performance. The secondary data on Commercial Banks, Foreign Banks, Investment Banks, Insurance Companies, Development Finance Institutions (DFIs), Leasing Companies, Mutual Funds, Modaraba Companies and Housing Finance Companies are collected from Financial Statement Analysis (FSA) from 2008 to 2016 provided by Statistics and DWH Department of State Bank, Pakistan. This study used Debt to Asset Ratio (DTA) as dependent variable and dummy of firm performance while Cost to Income Ratio (CTI), Enterprise Risk Management (ERM), Equity to Asset Ratio (ETA), Enterprise Value to Asset Value (EVTAV), Leverage (LVG), Return on Capital Employed (ROCE) and Return on Equity (ROE) are used as independent variables. The research found long run relationship among the variables. OLS Regression Test that Enterprise Risk Management (ERM) implementation, Equity to Asset Ratio (ETA), Enterprise Value to Asset Value (EVTAV), Leverage (LVG), Return on Capital Employed (ROCE), Return on Equity (ROE) have significant effect on performance of financial 
firms in positive direction while Cost to Income Ratio (CTI) have insignificant impact on performance of financial firms.

Key words: Enterprise Risk Management; Firm Value; Financial Indicators; Financial Sector.

\section{Introduction}

Enterprise faces manykinds of hazards or risks and therefore the attention differs across institutions and organizations. Numerous views used to define, explain, classify and understand the risk. The outline of risk between experts ranges from irregularities within theworth of financial variable to numerouskinds of planned or strategic variables. Skipper (1997) describes risk has no general or common definition and a techniqueto precise it because the unpredictability of results. Shimpi's (2001) point of view about risk is"the lifeblood of each association and practical administrators do be able to manage risk where it seems". Gupta (2004) declares risk discusses to the chance of deviation from the quality route. This variation lowersthe worth and suggest miserablethings.

Lin (2012) described that ERM consolidation approach can add firm value in few ways. First, by assessing all risks firms can develop a big picture of their risk portfolio. Second, through ERM companies can rank risk features according to their own risk management needs. Integrated risk management is essential to make a company more prepared to face and handle the risks. This approach leads to positive relation between ERM understanding and addition in firm value.

Risk varies from business to business. The elements of risk are regardingcoping with uncertainty. it'sbasicallysomething that has some impact on the long-run success of your business involvedmay be a risk. There are different levels of the danger with the different result implications however face challenges and build best plans to handle them. James jam defines the danger as a broad and well-organized structure for managing different varieties of risk like credit, marketplace, operative, economical or capital risks and risk transmission to maximize organization worth. Enterprise Risk Management relativelymay be amodern term in business and ultimately this approach is employed to manage the danger.

Financial firms play a crucial role within the economy. They act as mediators between the excess and deficit elements and this mediator part is vital for the efficient distribution of resources within the economy. The strength of the wide-ranging economycould be the advanced successful strategies, regulatory bodies and management tools.

Enterprise risk management (ERM) is amore important strategy that tries to measure and manage all the risks faced by the firm. So, ERM uses the firm's risk levels to seethat which 
level of risk must be accepted or must be satisfied or avoided. Whereas there has a significant growth in professional innovations of ERM in current years, very slighteducationalanalysis happens regarding ERM, and especiallyaboutthe implications of ERM on firm performance.

\section{Literature review:}

In 2010 RevistaExame, described the association between Enterprise risk management (ERM) and the development of firm performance in financial firms of Brazil. He conducted a survey research 500 biggest and best registered firms in Brazil. These 65 companies used as sample in this research.The sample consists of 200 companies. This research described that the Enterprise risk management was a technical issue for Brazilian companies because of lack of significant results. They showed negative relationship between ERM and the development of firm performance.

Afterwards, Pagach and Warr (2010) described the adoption of Enterprise risk management (ERM) effects on long-lasting performance of the firms. They analyzed data of 106 companies from 1992 to 2004. They implemented ERM statements of senior risk officers(SRO) to examine fluctuations in the financial sector. The findings of their study suitable for minor control tests. They also raised up the question whether ERM was achieving its objectives or not. Their result not succeeds to find that ERM was generates more firm value.

In further studies, Herbane (2010) examined that top-managers can manage risks by keeping their eyes open on possible risks in daily management. The sample declared that the companies managed by owners through applying formal management practices shows different aspects than companies that were not managed by owner managers. Mostly enterprises when adopted less ERM principles and owner management strategies results reduction in firm value.

Herbane study was further continued by Arena and Hoyt et al., (2010). According to them this would be an understood signal that the adoption of Enterprise risk management (ERM) were expected to have a significant effect on the performance of company's strategies. The results showed negative affiliation between both these factors.

Later in the same time frame (2010), The Dodd-Frank founded the Federal Insurance Offices to study the general risks imposed by insurance companies. Insurance companies faced mostly default risk of their customers while investment. Mainly variations were consisting on capital issues which negatively drops firms value. In reply to these variations implementation of Enterprise risk management enhanced by most of the insurers and financial firms. ERM procedures when adopted cause positive effect on lowering the default risk. 
Based on an inspection of 131 large financial organizations survey, Deloitte (2011) responds that seventy-nine firms out of a hundred had adopts ERM. By analyzing previous studies 67 Percent risk management plans placed in 2010. On the other hand, positive boost of 59 percent adopted in 2008. An assumption of this literature was that ERM adoption was value generating for insurers. Additionally, by analyzing previous studies from 1998 to 2005, Hoyt and Liebenberg (2011) examined United State insurance companies. The sample consists of 275 United state insurance companies to examine both the factors, without ERM adoption and the results after the adoption of ERM on organizations worth. In their experimental study, ERM used as dummy variable just for identify an insurer who involved in ERM adoption in a specified year under study. The results of insurance company's analyses showed strong positive relationship that doubled firms value after adoption of ERM.

In 2011, Subhani and Osman defined Enterprise Risk Management in an organization for controlling and handling the risk. Their primary concern of research was to study the ERM in two major subdivisions which were developed and undeveloped countries. Their results emphasized that very few organizations from undeveloped countries were involved in ERM. On the other hand, the organizations of developed countries were motivated and actively participates in ERM. Undeveloped countries must take notice on actions and strategies of ERM adopters. They also could generate firm value like others by ERM implementation.

Tahir and Razali (2011) discussed the impacts of Enterprise risk management and its improvements over the years. Its results showed that risk management cannot be handling from split or divided approach. It must be incorporated in a complete way. On the other hand they investigated the association among Enterprise risk management and firm value. In another survey the data collected from 528 Malaysian firms of 2007. Their study founds statically important relations among ERM and firm value.

Pagach and Warr (2011), observed the companies which adopting ERM, finding that companies adopt ERM for economic profit rather than for just supervisory pressure. Further, McShane, Nair and Elzotbek (2011) worked on data set of insurance groups consists of 152 companies. They study the effect of risk management activities on firm value. They use Standard \& Poor's model as an ERM rating through publicly traded insurers. Their result discovered a positive association among a growing level of risk management and firm value.

According to Hoyt and Liebenberg (2011), Enterprise Risk Management had the main issue in current years. The objective of their study was to control the amount which specific companies have implemented in ERM programs.After that to evaluate the value implemented on these plans, they focused on insurance firms of United States. They inspect these firms trends for the 11-years period from 1995 to 2005. The purpose was to check the association between the value and ERM of 275 insurance firms that operated during these years. Their 
study found that an extremely strong relation existed among firm value and enterprise risk management.

Lai \& Samad (2011) inspected the strength of ERM implementation in the state. They used variables such as financial costs, low tax load, costly external financing, agency-based problems and information irregularity as key elements of ERM implementation through product movement relationship tests. The result shows that ERM implementation has significant positive relationship with all these variables.

In addition, Aebi (2012) after searching trends of insurance companies, find signs of implementing ERM trend in banking and insurance corporations. The purpose was to create investor value by reducing earnings instability and enhancing performance. When financial disaster effects whole economies of numerous countries connected with the study of Hoyt and Liebnenberg (2011). He analyzed data of insurance companies, collection of 275 United states from 1998 to 2005 . He examined individually elements of risk management and firm value. At the end of the sample time frame, the results of 2006 show positive bank performance and low level of risk faced by insurance companies.

The aim of Golshan and Rasid (2012) was to see significant and powerful aspects of ERM implementation in Malaysian public listed companies. The two aspects of financial leverage and auditor classes were found to be significant and powerful aspects for ERM implementation.

Furthermore, Lin, Wen and $\mathrm{Yu}$ (2012) studies the association among ERM and different entity risk management practices. Their paper presented an academic base to observe the strategic elements, risk combination and value formation of ERM. They inspected hypotheses through proofs of United States insurance industry. Their results showed that insurers through high reinsurance investment and higher environmental diversity were more likely adopted ERM. Afterwards, Baxter et al., (2013) described that high-quality ERM programs are positively related with operational performance for firms in the banking and insuranceindustries. The market responds negatively to ERM implementation. ERM show a solid negative relationship with firm value regarding market.

Moreover, study of Lie (2014) consists on the ERM and firm value relationship. His study was supposed in the assessment of Chinese insurance industry. His results show that the ERM effects firms value positively and the regression line also showed the similar trend between both these variables. Therefore, it was suggested that the insurers of China were never in the favor of aggressive investment in ERM. Eckles et al., (2014) reports that the companies having strong institutional structure because of ERM adoption, reports less instable valuesof their shares. 
Further, Eckles, Hoyt and Miller (2014), describes that ERM can support a firm to diversify risks and to reduce return volatility. They suggested various ideas of reducing risk and for enhancement of firm value, like investing in more projects to avoid big loses. They observe the effect of risk reduction in insurance industries by examine enterprise risk management on the marginal cost. Their results shown had two different aspects like firms which adopt ERM experienced a big decrease in volatility of stock. Thus, more unpredictable firms get more benefits from implementing ERM programs.According to Jing, Bajtelsmit\& Wang (2014), ERM adoption and implementation activities were considered costly and time consuming. So different firms take it differently and implementation benefits varies from firm to firm.

An experimental study by Obalola et al., (2014) they studied the impacts of ERM adoption on Nigerian insurance firms. By collecting data over 10 years to understand the gap created in cost benefit strategy. They found constant improvement in the performance of insurance companies that accepted ERM. The famous study by Farrell and Gallagher (2015) shows statistically significant relations in Enterprise risk management and firm value. Also suggesting that an established level of ERM is linked with higher firm value. In this regard, most articles conclude a (significant) positive association between ERM and firm size. Firms with an ERM system are assumed to be able to make suitable economic decisions, to participate in more valuable projects.

A study by Dabari\&Saidin (2015), examined the intensity of ERM implementation in the country's (Malaysia) banking sector. By taking internal audit usefulness, human resource capability and controlling influence as independent variables. The result discovered that there is a positive significant association between all the active practices (internal audit effectiveness, human resource capability and controlling influence). So, the stage of ERM implementation with $89 \%$ full execution while ERM partial executionis only $11 \%$.

Henschel and Durst (2016) studied small firms in China, Germany, and Scotland exposes that small owner-managed firms are less likely to utilize risk management methods. These findings from quantitative research were added by understandings from qualitative studies. Which suggesting that if owner-managed firms engage in risk management, they rather do so in an informal or unspoken way (e.g., Gao et al., 2013; Herbane, 2010; Poba-Nzaou et al., 2014)

In addition, the existing studies of Callahan and Soileau (2017) have disclosed that ERM effects, depends on the maturity of ERM execution. It showed a huge difference in results between fully or partially adoption of risk management strategies. So that firms with complete adoption of ERM processes attain greater operative performance than those with less adoption of risk management process. Other experimental results show that firms with innovative levels of ERM implementation present higher performance, both as economic performance and as market assessment (Florio and Leoni, 2017). 


\section{Theoretical Framework:}

\section{Stakeholder Theory:}

Stakeholder theory was presented by Dr. F. Edward Freeman in 1984in his book, "Strategic Management: A Stakeholder Approach." This theory postulate that main objective of organization is to create and maximize value for stakeholders. According to this theory, stakeholders is much broader term than shareholders. Stakeholders are group or individual that are directly or indirectly related to the organization and have interest in organization profit and risk associated with it. Freeman's theory suggests that real success of organizationis lies in satisfaction ofall stakeholders.In other words, this theory demands that all stakeholders interests should be considered, which will present the will of organization. Therefore, stakeholder theory related to business ethics and organizational management. According to Zahid and Ghazali(2017)general belief of stakeholder theory is that stakeholders are asset of firm and their satisfaction is responsibility of management. While according to Aziz et al., (2015) all stakeholders have interest in objectives, business activities and behavior of organization. Therefore, it is necessary for organization to disclose its information to stakeholders and they have right to know about organization as well, which can increase their satisfaction level and good will of organization as well. Reporting information about business, economical, environmental and social aspects determined that organization accomplished part of its contract and organization activities match with the environment and value system of society. In the content of this theory, it is established that efficient risk management and corporate management practices and reporting about the sustainability of organization can increase the value of the organization.

\section{Modern Portfolio Theory:}

Modern Portfolio Theory was presented by Harry Markowitz in 1952 and published by Journal of Finance. This theory related to risk and return trade-off. It emphasized on the "responsibility of management in selecting investments at an efficient frontier line which produces a higher return" (Markowitz, 1952).According to modern portfolio theory risks are divided into two categories i.e. systematic and unsystematic risks. Systematic risks can not be controlled because it relates to the market, while unsystematic risks can be controlled through diversification of business (Aziz et al., 2015).This theory is also known as "portfolio theory" or "portfolio management theory", it highlight that there is possibility to structure such a effective and efficient portfolio which gives maximum possible return with minimum level of risk.Hence modern portfolio theory have important implication of risk mitigation by investing in efficient frontier which reduce overall risk of organization and increase value for stakeholders as well.In the light of this theory it can be formulated that risk management or risk mitigation team is necessary for organization which increase their performance, returns and firm value as well. 


\section{Trade off Theory:}

Trade off theory postulate that return is associated with the risk taken. This theory explains potential return is increase with the increasing risk i.e. higher risk have high probability of higher return while low risk is associated with high probability of low return. Therefore, investor facing low level of uncertainty or risk will face low level of return or gain and investor which face high level of uncertainty or risk will face high level of return or gain. The tradeoff which investors estimate between risk and return while making investment decisions is known as risk and return trade off. While making decision about investment, it is important to understand how much quantity of risk organization can bear. In the content of risk and return trade off theory it is established that choosing a good management panel is essential for firm that fits in running business. Effectivemanagement can consider the situation of running business, ERM Leadership and can highlights features of risks which need active initiative(Nocco and Stulz, 2006).

\section{Variable Description:}

Debt to Asset Ratio (DTA) is the dependent variable of the study, it is the total liabilities to total assets ratio. DTA shows the performance of the company, therefore used as dummy of firm performance.If DTA value is high it means company have to pay most of its profit as payment of principal debts. Therefore, a low value DTA is always better choice for investment. While Equity to Asset Ratio (ETA) is the ration between total equity and total assets. It shows the performance of company and used as independent variable. ETA is also known as solvency ratio, because it tells about the assets that are financed by owners as compared to total assets of the company. Therefore, higher value of ETA is more favorable because it attract investors and creditors. Another independent variable is Enterprise Risk Management (ERM) which shows how the company is managing the risk. If proper risk management team, frame work or department is present in company its mean company is implementing ERM. ERM is the binary variable if companies implement ERM then its value is 1 otherwise it will be zero(Aebi et al., 2012; Ellul \&Yerramilli, 2013; Eckles et al., 2014; Hoyt and Liebenberg, 2011; Pagach and Warr, 2011; Li, Wen and Yu, 2012; Golshan and Rasid, 2012).For identification of ERM we followed thestudy of Lechner \&Gatzert(2017), they told ERM can be identified by using following keywords; Chief Risk Officers (CFO), The ERM, COSO Integrated Framework, Risk Committee, Centralized Risk Management and Holistic Risk Management in the financial or annual reports of the companies. (Aebi, Sabato \& Schmid, 2012; Eckles, Hoyt\& Miller, 2014;Ellul \&Yerramilli, 2013; Hoyt \& Liebenberg, 2003\& 2011; Lin,Wen\& Yu, 2012; Pagach\& Warr, 2010).

Another performance measure is Cost to Income Ratio (CTI). It is the comparison between total operating cost with total income, which is used as independent variable following Battaglia et al., (2017). Operating expense comprise all the fixed expenses of the business 
such as insurance, rent and taxes etc. CTI measures the cost of running business with comparison to total income of the business and it gauge the business efficiency. Therefore, low CTI means cost of business is low as compared to income, so low CTI is more favorable. Another independent variable which measure performance of company is Enterprise Value to Asset Valuation (EVTAV), which is ratio between enterprise value and total assets. Enterprise value of banks is combination of Long term finance certificates, Long term security deposit, Liabilities against assets subject to finance lease, Redeemable capital, Longterm finance, Long term deposits on lease contracts, Musharakah term finance certificates, Long term morabaha etc. Similarly enterprise value of insurance companies include Amount due to other insurers / reinsurers, Obligations under finance lease, Unclaimed Dividend Payable, Premiums Received in Advance, Liability against asset finance lease, Deposits and other payables, Retained from retrocessionaires, Reserve for incurred but not reported claims, Amounts due to other takaful / retakaful operators, Deposits received against bonds, Finances under mark-up arrangements (secured), Contribution received in advance, Amount due to retakaful companies and Contribution deficiency reserve etc. While enterprise value of mutual fund includes Unclaimed dividend and Dividend payables and enterprise value of modaraba companies include Liability against ijarah finance, Lease deposits, Diminishing Musharaka based Term Finance Certificates, Long term portion of Musharaka, Murabaha and Finance under mark-up arrangements, Finance under morabaha arrangement, Long term portion of redeemable capital, Long term certificates of musharaka, Long term finances, Long term musharaka finance secured, Long term morabaha finances (secured) and Long term portion of ijarah deposits etc.

Return on Capital Employed(ROCE) is the independent firm performance variable which is ratio between net income and capital employed, while capital employed include shareholder equity and debt liabilities. Capital employed can be calculated by subtracting current liabilities from total assets. ROCE is the long term profitability ratio which take consideration of long term finances and measures the efficiency or performance of firm by calculating how efficiently firm produce profit on its capital employed. Higher value of ROCE is favorable because it shows more profit on applied capital. SimilarlyReturn on Equity(ROE) is the profitability ratio between net income and shareholder's equity. It means ROE is measuring how much a firm is making profit on shareholder's equity, following Soliman et al., (2018) andK. Alawattegama (2017). Therefore, higher ROE value is favorable. While leverage (LVG) is the ratio between book value of liabilities and book value of equity. It measure the performance of firm by calculating which degree of assets of firms is financed by debts and shareholder's equity, following Beasley et al.,2008, Hoyt and Liebenberg (2008\& 2011), Farrell and Gallagher (2015). Low value of LVG is favorable because high value of LVG shows that business relies mostly on external debts and such business is more risky to invest. 
International Journal of Innovation, Creativity and Change. www.ijicc.net

Volume 15, Issue 6, 2021

\section{$\underline{\text { Analysis: }}$}

Unit Root Test:

\begin{tabular}{|c|c|c|c|}
\hline \multicolumn{4}{|c|}{ Augmented Dickey-Fuller Test } \\
\hline Variables & I0 & P Value & Remarks \\
\hline Debt to Asset Ratio & -8.369688 & 0.0000 & \multirow{8}{*}{$\begin{array}{c}\text { All variables } \\
\text { have stationarity } \\
\text { at level. }\end{array}$} \\
\hline Equity to Asset Ratio & -8.669016 & 0.0000 & \\
\hline Enterprise Risk Management & -7.429128 & 0.0000 & \\
\hline Cost to Income Ratio & -29.62065 & 0.0000 & \\
\hline Enterprise Value to Asset Valuation & -9.218487 & 0.0000 & \\
\hline Return on Capital Employed & -20.21719 & 0.0000 & \\
\hline Return on Equity & -23.42139 & 0.0000 & \\
\hline Leverage & -25.84993 & 0.0000 & \\
\hline
\end{tabular}

To check the statistical stationarity of data Unit Root Test or Augmented Dickey-Fuller Test is applied on data, which show that Debt to Asset Ratio (DTA)has stationarity at level having significant results with value of -8.369688 ,Equity to Asset Ratio (ETA) has significant stationarity at level with value of -8.669016 , Enterprise Risk Management (ERM) has significant results of stationarity at level with value of -7.429128 , Cost to Income Ratio (CTI) also has stationarity at level with significant results having value of -29.62065 , Enterprise Value to Asset Valuation(EVTAV) has stationarity at level having significant results with value of -9.218487 , Return on Capital Employed(ROCE) has stationarity at level having significant results with value of -20.21719 , Return on Equity has significant results stationarity at level with value of -23.42139 and Leverage (LVG) also has stationarity at level with significant results having value of -25.84993 .

\section{Correlation:}

\begin{tabular}{|c|c|c|c|c|c|c|c|}
\hline Variables & CTI & DTA & ERM & ETA & EVTAV3 & LVG & ROCE \\
\hline DTA & 0.04197 & & & & & & \\
\hline ERM & 0.01856 & 0.42127 & & & & & \\
\hline ETA & -0.03758 & -0.94833 & -0.36711 & & & & \\
\hline EVTAV & -0.02230 & -0.24591 & 0.00914 & 0.32356 & & & \\
\hline LVG & 0.00003 & 0.14313 & 0.01056 & -0.14298 & -0.03850 & & \\
\hline ROCE & 0.01033 & -0.11363 & -0.04033 & 0.11145 & 0.10152 & -0.01959 & \\
\hline ROE & 0.00373 & -0.01874 & 0.01116 & 0.02914 & 0.07739 & -0.56836 & 0.45988 \\
\hline
\end{tabular}

Correlation test is applied on variables to check the association among variables, which shows that CTI and DTA have $4.2 \%$ of week positive correlation, CTI and ERM also have $1.9 \%$ of week positive correlation, CTI and LVG have $0.003 \%$ of very week positive correlation, CTI and ROCE have $1 \%$ of very week positive correlation similarly CTI and ROE have $0.4 \%$ of very week positive correlation. While CTI and ETA have $-3.8 \%$ of week 
International Journal of Innovation, Creativity and Change. www.ijicc.net

Volume 15, Issue 6, 2021

negative correlation, similarly CTI and EVTAV have $-2.2 \%$ of week negative correlation. DTA and ERM have $42.1 \%$ of positive moderate correlation. DTA and ETA have $-94.8 \%$ of very strong negative correlation. As the relationship is more than $90 \%$, therefore multicollinearity may exist between these variables. DTA and EVTAV have $-24.6 \%$ of week negative correlation, DTA and LVG have $14.3 \%$ of week positive correlation, DTA and ROCE have $-11.4 \%$ of week negative correlation, DTA and ROE have $-1.9 \%$ of very week negative correlation.In the same way ERM and ETA have $-36.7 \%$ of moderate negative correlation, ERM and EVTAV have $0.9 \%$ of very week positive correlation, ERM and LVG have $1.1 \%$ of very week positive correlation, ERM and ROCE have $-4.0 \%$ of very week negative correlation, ERM and ROE have $1.1 \%$ of very week positive correlation. Meanwhile, ETA and EVTAV have $32.4 \%$ of moderate negative correlation, ETA and LVG have $-14.3 \%$ of week negative correlation, ETA and ROCE have $11.1 \%$ of week positive correlation, ETA and ROE have $2.9 \%$ of week positive correlation. Similarly, EVTAV and LVG have $-3.9 \%$ of week negative correlation, EVTAV and ROCE have 10.2\% of week positive correlation, EVTAV and ROE have $7.7 \%$ of week positive correlation.In the same way, LVG and ROCE have $-2.0 \%$ of week negative correlation, LVG and ROE have $-56.8 \%$ of moderate negative correlation. While ROCE and ROE have $45.9 \%$ of moderate positive correlation.

Johansen Cointegration Test:

\begin{tabular}{|c|c|c|c|c|}
\hline \multicolumn{5}{|c|}{ Johansen Cointegration Test } \\
\hline $\begin{array}{c}\text { Hypothesized No. } \\
\text { of CE(s) }\end{array}$ & Eigenvalue & $\begin{array}{c}\text { Trace } \\
\text { Statistic }\end{array}$ & $\begin{array}{c}\text { Critical } \\
\text { Value }\end{array}$ & Prob.** \\
\hline None * & 0.196444 & 800.6878 & 175.1715 & 0.0000 \\
\hline At most 1 * & 0.182885 & 608.8801 & 139.2753 & 0.0001 \\
\hline At most 2 * & 0.124890 & 431.7481 & 107.3466 & 0.0001 \\
\hline At most 3 * & 0.107051 & 314.7509 & 79.34145 & 0.0000 \\
\hline At most 4 * & 0.090112 & 215.4518 & 55.24578 & 0.0000 \\
\hline At most 5 * & 0.065886 & 132.6334 & 35.01090 & 0.0000 \\
\hline At most 6 * & 0.053329 & 72.85962 & 18.39771 & 0.0001 \\
\hline At most 7 * & 0.027878 & 24.79663 & 3.841466 & 0.0000 \\
\hline
\end{tabular}

Johansen Cointegration Test results show that trace value of first variable (800.6878) is higher than its Critical Value (175.1715) with p-value of 0.0 with in level of significance, Second variable trace value (608.8801) is higher than its Critical Value (139.2753) with pvalue of 0.0001 with in level of significance, third variable trace value (431.7481) is higher than its Critical Value (107.3466) with p-value of 0.0001 with in level of significance, fourth variable trace value (314.7509) is higher than its Critical Value (79.34145) with p-value of 0.0 with in level of significance, fifth variable trace value $(215.4518)$ is higher than its Critical Value (55.24578) with p-value of 0.0 with in level of significance, sixth variable trace value (132.6334) is higher than its Critical Value (35.01090) with p-value of 0.0 with in level of significance, seventh variable trace value (72.85962) is higher than its Critical Value (18.39771) with p-value of 0.0001 with in level of significance, eighth variable trace value 
International Journal of Innovation, Creativity and Change. www.ijicc.net

Volume 15, Issue 6, 2021

(24.79663) is higher than its Critical Value (3.841466) with p-value of 0.0 with in level of significance.

\begin{tabular}{|c|c|c|c|c|}
\hline $\begin{array}{c}\text { Hypothesized } \\
\text { No. of CE(s) }\end{array}$ & Eigenvalue & $\begin{array}{c}\text { Max-Eigen } \\
\text { Statistic }\end{array}$ & $\begin{array}{c}\text { 0.05 Critical } \\
\text { Value }\end{array}$ & Prob.** \\
\hline None * & 0.196444 & 191.8077 & 55.72819 & 0.0000 \\
\hline At most 1 * & 0.182885 & 177.1320 & 49.58633 & 0.0000 \\
\hline At most 2 * & 0.124890 & 116.9971 & 43.41977 & 0.0000 \\
\hline At most 3 * & 0.107051 & 99.29915 & 37.16359 & 0.0000 \\
\hline At most 4 * & 0.090112 & 82.81837 & 30.81507 & 0.0000 \\
\hline At most 5 * & 0.065886 & 59.77378 & 24.25202 & 0.0000 \\
\hline At most 6 * & 0.053329 & 48.06299 & 17.14769 & 0.0000 \\
\hline At most 7 * & 0.027878 & 24.79663 & 3.841466 & 0.0000 \\
\hline
\end{tabular}

Similarly Johansen Cointegration Test results show that Max-Eigen Statistic of first variable (191.8077) is higher than its Critical Value (55.72819) with p-value of 0.0 with in level of significance, Second variable Max-Eigen Statistic (177.1320) is higher than its Critical Value (49.58633) with p-value of 0.0 with in level of significance, third variable Max-Eigen Statistic (116.9971) is higher than its Critical Value (43.41977) with p-value of 0.0with in level of significance, fourth variable Max-Eigen Statistic (99.29915) is higher than its Critical Value (37.16359) with p-value of 0.0 with in level of significance, fifth variable Max-Eigen Statistic (82.81837) is higher than its Critical Value (30.81507) with p-value of 0.0 with in level of significance, sixth variable Max-Eigen Statistic (59.77378) is higher than its Critical Value (24.25202) with p-value of 0.0 with in level of significance, seventh variable MaxEigen Statistic (48.06299) is higher than its Critical Value (17.14769) with p-value of 0.0with in level of significance, eighth variable Max-Eigen Statistic (24.79663) is higher than its Critical Value (3.841466) with p-value of 0.0 with in level of significance.

Overall results of Johansen Cointegration Test results show that all variables have steric mark on it which means our study variables have long term association among them. All variables have significant results while having Trace Statistic of each variable is higher than Critical Value of that variable. Similarly Max-Eigen Statistic of each variable is higher than critical value of that variable with significant results of each variable, shows that all variables have long term association among them.

\section{OLS Regression:}

The model of our study is: -

$$
\begin{aligned}
& D T A=C(1)+C(2) * C T I+C(3) * E R M+C(4) * E T A+C(5) * E V T A V 3+C(6) * L V G \\
& +C(7) * R O C E+C(8) * R O E-E q[1] \\
& D T A=C+\beta_{1} C T I+\beta_{2} E R M+\beta_{3} E T A+\beta_{4} E V T A V+\beta_{5} R O C E+\beta_{6} R O E+\beta_{7} L V G \\
& \text { - Eq[2] }
\end{aligned}
$$


International Journal of Innovation, Creativity and Change. www.ijicc.net

Volume 15, Issue 6, 2021

\begin{tabular}{|c|c|c|c|c|}
\hline \multicolumn{5}{|c|}{ OLS Regression } \\
\hline Variables & Coefficient & t-Statistic & Prob. & VIF \\
\hline Constant & 0.8922 & 91.1070 & 0.0000 & - \\
\hline ERM & 0.0550 & 6.9179 & 0.0000 & 1.184 \\
\hline ETA & -0.9721 & -77.5806 & 0.0000 & 1.388 \\
\hline EVTAV & 0.0595 & 5.1575 & 0.0000 & 1.152 \\
\hline LVG & 0.0002 & 2.1355 & 0.0330 & 1.738 \\
\hline ROCE & -0.0293 & -2.1405 & 0.0326 & 1.469 \\
\hline ROE & 0.0070 & 2.1118 & 0.0350 & 2.160 \\
\hline CTI & 0.0001 & 0.6800 & 0.4967 & 1.002 \\
\hline
\end{tabular}

OLS Regression test is applied to check the magnitude and direction among the dependent and independent variables. Debt to Asset Ratio (DTA) is used as dependent variable and dummy of firm performance while Cost to Income Ratio (CTI), Enterprise Risk Management (ERM), Equity to Asset Ratio (ETA), Enterprise Value to Asset Value (EVTAV), Leverage (LVG), Return on Capital Employed (ROCE) and Return on Equity (ROE) are used as independent variables. OLS Regression test shows that Enterprise Risk Management (ERM)is significant having 0.8922 magnitude and positive direction, Equity to Asset Ratio (ETA) is significant having -0.9721 magnitude in negative direction, Enterprise Value to Asset Value (EVTAV)is significant having 0.0595 magnitude in positive direction, Leverage (LVG) is significant having 0.0002 magnitude in positive direction, Return on Capital Employed (ROCE)is also significant having 0.0070 magnitude in positive direction, while Cost to Income Ratio (CTI) has insignificant results with 0.0001 magnitude.

Similarly, Enterprise Risk Management (ERM) has1.184 value of VIF, Equity to Asset Ratio (ETA) have 1.388 value of VIF, Enterprise Value to Asset Value (EVTAV) has 1.152 value of VIF, Leverage (LVG) has 1.738 value of VIF, Return on Capital Employed (ROCE) has 1.469 value of VIF, Return on Equity (ROE) has 2.160 value of VIF and Cost to Income Ratio (CTI) has 1.002 value of VIF. All variables have VIF value within limit, therefore there is no multicollinearity among variables, which have highlighted in correlation test.

\begin{tabular}{|c|c|c|c|}
\hline F Value & P Value & Adjusted R-squared & Durbin-Watson Stat \\
\hline 1249.218 & 0.000000 & 0.908406 & 0.629569 \\
\hline
\end{tabular}

Adjusted R-square is $90 \%$ fitness of model, similarly F-value has significant results. While Durbin-Watson Statistics shows that there is positive inter-association among variables.

After the analysis of magnitude and direction through OLS Regression test, the equation will now become:-

$$
\begin{array}{r}
D T A=0.8922+0.0001 C T I+0.0550 E R M-0.9721 E T A+0.0595 E V T A V \\
+0.0002 R O C E-0.0293 R O E+0.0070 L V G \quad-E q[3]
\end{array}
$$




\section{Conclusion:}

The purpose of this study is to check the impact of Enterprise Risk Management (ERM) on performance of financial firms of Pakistan. For this purpose data is collected from Financial Statement Analysis (FSA)from 2008 to 2016 provided by Statistics and DWH Department of State Bank, Pakistan. A sample of 98 financial firms of Pakistan has been selected for this study as per availability of data from 2008 to 2016.Sample include Commercial Banks, Foreign Banks, Investment Banks, Insurance Companies, Development Finance Institutions (DFIs), Leasing Companies, Mutual Funds, Modaraba Companiesand Housing Finance Companies. This study used Debt to Asset Ratio (DTA) as dependent variable and dummy of firm performance while Cost to Income Ratio (CTI), Enterprise Risk Management (ERM), Equity to Asset Ratio (ETA), Enterprise Value to Asset Value (EVTAV), Leverage (LVG), Return on Capital Employed (ROCE) and Return on Equity (ROE) are used as independent variables.

To check the stationarity of data Unit Root Test or Augmented Dickey-Fuller Test is applied. Results show that all variables have stationarity at level with significant magnitudes of Debt to Asset Ratio (DTA) is -8.369688 , Equity to Asset Ratio (ETA) magnitude is -8.669016, Enterprise Risk Management (ERM) magnitude is -7.429128, Cost to Income Ratio (CTI) magnitude is -29.62065, Enterprise Value to Asset Valuation (EVTAV) magnitude is 9.218487, Return on Capital Employed (ROCE) magnitude is -20.21719 , Return on Equity magnitude is -23.42139 and Leverage (LVG) magnitude is -25.84993, which is normally not happens for financial firms data but our study is based on comparison of different ratios of firm performance and ratios have some issue with stationarity because financial firmsadjust their annual reports is such a way that all ratios give positive gesture about firm. Therefore, financial firms data show stationarity at level. To check the association among variables correlation test is applied which shows some variables have week and some have moderate correlation among them in negative and positive directions as well. Results also show that Debt to Asset Ratio (DTA) and Equity to Asset Ratio (ETA) have $-94.8 \%$ of very strong negative correlation, which may lead towards multicollinearity between these two variables. But later on OLS Regression results (VIF value) show that, there is no multicollinearity between any variables. Similarly Durban Watson value shows positive inter-association among variables. Johansen Cointegration Test is applied to check long term or short term association among variables, which show long term association among variables. For direction and magnitude OLS Regression Test is applied results show that Enterprise Risk Management (ERM) is significant having 0.8922 magnitude and positive direction, Equity to Asset Ratio (ETA) is significant having -0.9721 magnitude in negative direction, Enterprise Value to Asset Value (EVTAV) is significant having 0.0595 magnitude in positive direction, Leverage (LVG) is significant having 0.0002 magnitude in positive direction, Return on Capital Employed (ROCE) is also significant having 0.0070 magnitude in positive direction, 
while Cost to Income Ratio (CTI) has insignificant results with 0.0001 magnitude. as studied by Battaglia et al., (2017).

Similarly VIF values of variables (Enterprise Risk Management $(E R M)=1.184$, Equity to Asset Ratio $(E T A)=1.388$, Enterprise Value to Asset Value $($ EVTAV) $=1.152$, Leverage $(\mathrm{LVG})=1.738$, Return on Capital Employed $(\mathrm{ROCE})=1.469$, Return on Equity $(\mathrm{ROE})=$ 2.160, Cost to Income Ratio $(\mathrm{CTI})=1.002)$ are within limit, show that there is no multicollinearity among variables, which hasbeen highlighted in correlation test.

Our study overall results show thatEnterprise Risk Management (ERM) implementation, Equity to Asset Ratio (ETA), Enterprise Value to Asset Value (EVTAV), Leverage (LVG), Return on Capital Employed (ROCE), Return on Equity (ROE)have significant effect on performance of financial firms in positive direction while Cost to Income Ratio (CTI) have insignificant impact on performance of financial firms. 
International Journal of Innovation, Creativity and Change. www.ijicc.net

Volume 15, Issue 6, 2021

\section{REFERENCES}

Aebi, V., Sabato, G., \& Schmid, M. (2012). Risk management, corporate governance and bank

Alawattegama,K. (2017). The Impact of Enterprise Risk Management on Firm Performance: Evidence from Sri Lankan Banking and Finance Industry. International Journal of Business and Management, 13(1).

Arena, M., Arnaboldi, M. \&Azzone, G. (2010). The organizational dynamics of enterprise risk management. Accounting, Organizations and Society, 35(7), pp 659-675.

Aziz, N. A. A., Manab, N. A. \& Othman, S. N. (2015). Exploring the perspectives of corporate governance and theories on sustainability risk management (SRM). Asian Economic and Financial Review, 5(10), pp 1148.

Battaglia, F., Fiordelisi. F., \& Ricci O. (2017). Enterprise Risk Management and Bank Performance: Evidence from Eastern Europe during the Financial Crisis. In Risk Management in Emerging Markets, pp 295-334.

Berry-Stoelzle, T.R. \& Hoyt, R.E. (2011). Implementation of enterprise risk management: evidence from the German property-liability insurance industry. Geneva Pap.Risk Insur. Issues Pract, 36, pp 414-439.

Dabari, I. J. \&Saidin, S. Z. (2015). A theoretical framework on the level of risk management implementation in the Nigerian banking sector: The moderating effect of top management support. Procedia-Social and Behavioural Sciences, 164, pp 627-634.

Eckles, D. L., Hoyt, R. E., \& Miller, S. M. (2014). The impact of enterprise risk management on the marginal cost of reducing risk: Evidence from the insurance industry. Journal of Banking \& Finance, 43, pp 247-261.

Ellul, A., \&Yerramilli, V. (2013). Stronger risk controls, lower risk: Evidence from U.S. bank holding companies. The Journal of Finance, 68, pp 1757-1803.

Farrell, M. \& Gallagher, R. (2015). The valuation implications of enterprise risk management maturity. Journal of Risk and Insurance, 85(3), pp 625-657.

firm value: evidence from Malaysian public listed companies. International Journal ofEconomics and Management Sciences, 1(2), pp 32-41.

Golshan, N., \&Rasid, S. (2012). Determinants of Enterprise Risk Management Adoption: An Empirical Analysis of Malaysian Public Listed Firms. International Journal of Social and Human Sciences, 6(1), pp 119-126.

Hoyt, R. E., \& Liebenberg, A. P. (2011). The Value of Enterprise Risk Management. Journal of Risk and Insurance, 78(4), pp 795-822.

Lai, F. \& Samad, F. (2011). Enterprise risk management and the empirical drivers of Its implementation. 10 International Conference on Businessand Economics Research, 1.

Lechner, P. \&Gatzert, N. (2017). Determinants and value of enterprise risk management: empirical evidence from Germany. The European Journal of Finance, pp 1-27. 
International Journal of Innovation, Creativity and Change. www.ijicc.net

Volume 15, Issue 6, 2021

Liebenberg, A.P. \& Hoyt, R.E. (2003). The determinants of enterprise risk management: Evidence from the appointment of chief risk officers. Risk Management and Insurance Review, 6, pp 37-52.

Lin, Y., Wen, M. \& Yu, J. (2012). Enterprise risk management: strategic antecedents, risk integration and performance. North Am. Actuar, 16(1), pp 1-28.

Markowitz, H. M. (1952). Portfolio selection. Journal of Finance, 7, pp 77-91.

McShane, M., Nair, A., \&Rustambekov, E. (2011). Does enterprise risk management increase firm value? Journal of Accounting, Auditing \& Finance, 16(4),pp 641-658.

Nocco, B.W. \&Stulz, M (2006). Enterprise risk management: Theory and practice. Journal ofApplied Corporate Finance, 18(4), pp 1-13.

Obalola, M. A., Akpan, T. I., \&Abass, O. A. (2014). The Relationship between Enterprise Risk Management (ERM) and Organizational Performance: Evidence from Nigerian Insurance Industry. Research Journal of Finance and Accounting, 5(14), pp 152-161.

Pagach, D. \& Warr, R.(2010). The Effects of Enterprise Risk Management on Firm Performance. Working Paper. North Carolina State University, 49, pp 1-15.

Pagach, D. \& Warr, R.(2011). The characteristics of firms that hire chief risk officers. Risk Insur. ,78(1), pp 185-211.

performance in the financial crisis. Journal of Bank Finance, 32(2), pp 3213-3226.

RevistaExame (2010). Melhores e maiores: as 500 maioresempresas do Brasil.RevistaContabilidade\&Finanças, 21(53), pp 1-25.

Shimpi, P.(2001). The Value of Investing in Enterprise Risk Management.Journal of Risk andInsurance, 82 (2), pp 289-316.

Simkins, B. J. (2007). Ten common misconceptions about enterprise risk management. Journal of Applied Corporate Finance, 19(4), pp 75-81.

Soliman, A.M., Mukhtar,A.\&Shubita,F.M. (2018). The long term relationship between enterprise risk management and bank performance: the missing link in Nigeria. Banks and Bank Systems, 13(1), pp 128-138.

Subhani, M.I. \& Osman, A. (2011). The Essence of Enterprise Risk Management in Today's Business Enterprises in Developed and Developing Nations. European Journal of Social Sciences(EJSS).

Tahir, I., \& Razali, A. (2011). The relationship between enterprise risk management (ERM) and

Zahid, M. \& Ghazali, Z. (2017). Corporate sustainability practices and business's financial performance: The driving force of integrated management system. Global Business and Management Research, 9(1), pp 479. 